\title{
USING SPREADABLE TOFU BLENDS IN THE PREPARATION OF GROISSANTS
}

By

Shafika A. Zaki

Department of Food Science, Faculty of Agriculture, Cairo University, Giza, Egypt.

\section{Hala M. Nagi}

Department of Food Science, Faculty of Agriculture, Cairo University, Giza, Egypt.
Abeer F. Zayan

Dairy Research \& Technology Department, Food Tech. Res. Inst.,

Agric. Res. Center, Egypt

\section{Amira S. Abd-Elsalam}

Dairy Research \& Technology Department, Food Tech. Res. Inst.,

Agric. Res. Center, Egypt

Research gournal Specific Fducation

Faculty of Specific Education

glansoura University

ISSUE NO. 49, JANUARY. 2018

مجلة بعوث التربية النوعية - جامعة المنصورة

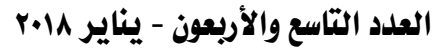




\section{USING SPREADABLE TOFU BLENDS IN THE PREPARATION OF CROISSANTS Shafika A. Zaki Hala M. Nagi * \\ Abeer F. Zayan \\ Amira S. Abd-Elsalam**}

\section{Abstract}

Soy protein (tofu) is the most inexpensive source of high nutritional quality protein. The biological value of soy protein is higher than that of casein. The study aimed to prepare croissant with spreadable tofu blends to enhance nutritional value and function. Spreadable tofu blends, with different flavors, were added to the croissant as filling materials. Seven samples were prepared. Samples included; control without addition, and with spreadable tofu only, tofu with chopped green olives, tofu with ground black pepper and chopped green peppers, tofu with sugar; tofu with guava pulp, and tofu with peach pulp. The croissant samples were subjected to chemical, physiological, microbiological and sensory assessment. Results indicated slight differences among treatments within the range of moisture. The protein, fat and ash contents in all the croissant samples stuffed with tofu were higher than the control sample. In contrast, control croissant showed higher carbohydrates content compared to the other samples. Water activity was decreased with extending storage time and addition of tofu mixtures. The sensory test of the croissant samples confirmed that the croissant samples with the tofu blends were more acceptable than the control sample and proved the superiority of the green olives sample and the peach sample among the formulated ones. The microbiological assay assured the safety of all samples.

Key words: croissant, spreadable tofu, chemical composition, water activity, sensory evaluation, microbiological examination.

${ }_{* *}^{*}$ Department of Food Science, Faculty of Agriculture, Cairo University, Giza, Egypt.

Dairy Research \& Technology Department, Food Tech. Res. Inst., Agric. Res. Center, Egypt. 


\section{Introduction:}

The use of soy as food ingredient has grown in food industry as a result of its health benefits, technological and functional properties (Petrak, 2008). Soy protein found to be the most inexpensive source of high nutritional quality protein, which the biological value of soy protein is higher than that of casein (Farahmandfar et al., 2010).

Therefore, unless following the advice from a registered dietitian or other health professional, consumers must be skeptical to all those currents and do not eliminate unnecessarily this whole food group because they provide a range of macro- and micronutrients and fiber (Aisbitt et al. 2008).

Dietary fiber, beta-glucan, resistant starch, carotenoids, phenolics, tocotrienols, and tocopherols have been related to disease prevention like cardiovascular diseases and strokes, hypertension, metabolic syndrome, type 2 diabetes mellitus, obesity, as well as different forms of cancer (Yu et al. 2012).

Cereal fiber have been repeatedly associated in the epidemiological literature with reduced mortality and risk of chronic disease (Smith and Tucker 2011; Borneo and León 2012).

Croissants, the delectable favorites on a French breakfast table, are prepared from lightly enriched yeast dough interleaved with thin layers of butter as dough is raised not only by yeast but also by the butters moisture, which tums to steam during baking and seperates the layers into light flakes (Rosell and Garzon, 2015).

\section{Materials and Methods}

\section{Materials}

Soybean seeds (Glycine Max., L., commercial variety) were obtained from Legumes Research Dep., Field Crops Research Institute, Agriculture Research Center, Giza, Egypt.

Wheat floure, margarinen, salt, yeast, sugar, nonfat dry milk from local market 
Plate count agar, McConky agar, Malt agar and Trypton soy agar media were obtained from Difco Co (USA).

\section{Methods}

\section{- Processing procedure of tofu from soymilk:}

1. Cooking soymilk in a steam jacketed kettle at $90-95^{\circ} \mathrm{C}$ for $15-20$ min. (Groen, Adover Industries Co., Elk village, USA).

2. Weighing $100 \mathrm{~kg}$ soymilk in bucket and reheat it at $85^{\circ} \mathrm{C}$.

3. Adding a warm coagulant powder $(0.5 \%$ calcium chloride $)$ to soymilk at $70-80{ }^{\circ} \mathrm{C}$ with agitation using a paddle.

4. After forming curd allowing it to stand for $15-20 \mathrm{~min}$.

5. Breaking up the curd evenly and transferring it using a ladle into a forming box lined with moistened cloth, and then covering the box with lid.

6. Pressing with a suitable pressure (at $50 \mathrm{psi}$ for 15-20 min).

7. Placing the forming box with tofu in a cooling tank, resetting to the tofu for $5 \mathrm{~min}$, unfolding the cloth and removing the tofu.

8. Cutting the tofu into pieces (about $3 \times 4 \times 5 \mathrm{~cm}$ ) (Benassi et al., 2011) and (Agrahar ,2014)

\section{- Preparation of Spreadable tofu blends with some materials}

The raw materials \{ soy curd (Tofu), whey proteins, palm oil, skim milk powder, stabilizers \{carboxymethylcellolose - Guar gum\}, emulsifying salts and water were added consecutively in laboratory processing Kettle (Thermomix TM 31 made in Australia Pty Ltd 2010) as mentioned by Awad et al., (2014).

Vegetable and fruits was added to the formula. The mixture was cooked for $10 \mathrm{~min}$ at $85-90^{\circ} \mathrm{C}$ using indirect steam at pressure $2-2.5 \mathrm{~kg} / \mathrm{cm} 2$. The mixture was hot filled into wide mouth glass jars and capped directly after filling. The formulations of the six spreadable tofu samples are shown in table 1 . 
- Preparation of croissant pastries samples with spreadable tofu blends:

Dough was prepared according to the method described by Sternhagen and Hoseney (1994). The ingredients consisted of $1 \mathrm{Kg}$ Wheat flour, 100g margarine, $15 \mathrm{~g}$ salt, $15 \mathrm{~g}$ yeast, $100 \mathrm{~g}$ sugar, $40 \mathrm{~g}$ nonfat dry milk and water to make dough after mixing, then the dough rested for $15 \mathrm{~min}$. before incorporating $0.500 \mathrm{Kg}$ of layering fat by envelop method. The paste was rested for $15 \mathrm{~min}$. more and gauged to thickness by using sheeter. After that the paste was cut into triangular pieces each piece $50 \mathrm{~g}$. The pastries were placed into a proofing cabinet and proofed at $85 \%$ humidity and $38 \mathrm{C}$ to $60 \mathrm{~min}$

Spreadable tofu enhanced with difference additives (30g) were added to 100 $\mathrm{g}$ croissant dough as filling materials, and then the pastries were baked at 205 for 10-15 min. Then, the croissant sample were wrapped with stretch film and stored at room temperature up to 4 days. The seven samples are shown in table 2.

\section{- Chemical analysis:}

Moisture, total proteins, fat and ash contents were determined as described in AOAC (2012). Carbohydrate content was calculated by subtraction of the sum of moisture, protein, fat and ash contents AOAC (2005)

\section{- Microbiological examinations:}

Total plate count (TPC) was recorded as colony numbers per gram of sample, yeast and mould count (Chikere and Udochukwu, 2014), detection of Coliform group, Staphylococci aureus and Listeria monocytogenes described in (Katase and Tsumura, 2011).

\section{- Sensory evaluation:}

The sensory properties of samples were determined by panel of judges who were familiar with the product using the hedonic scale where 1-10 represents dislike extremely to like extremely (Abou- Dobara, et al., 2016). Sensory characteristics (taste, odor, texture, crust color, crust appearance, 
lamination and volume) of croissant pastries were determined according to the methods described by Bennion and Bamford (1983).

\section{Results And Discussion}

\section{Chemical composition:}

The chemical composition of croissant samples with spreadable tofu products is illustrated in Figures 1- 5. Data showed slight differences among the treatments within the ranges of moisture contents (19.60-19.90).

Protein contents ranged between 8.48 and $10.96 \%$. Fat contents varied from 30.61 to $32.67 \%$ and ash fluctuated between 1.64 and $2.06 \%$. Protein, fat and ash contents in all samples with spreadable tofu were higher than control.

Treatment Ct6 (croissant filled with spreadable tofu and peach pulp) showed the highest moisture and ash, while Treatment Ct2 (croissant with spreadable tofu and Chopped green olive) had the highest protein and fat contents. In contrast, control croissant showed highest carbohydrates compared other samples.

These results were in harmony with Massoud et al. (2016) and Zeiny, et al.(2015) who noted that moisture content of croissant ranged from (17.80 - 22.94\%), and protein, fat contents and carbohydrates represented $10.27 \%, 32.11 \%$ and $43.97 \%$. Total carbohydrates were in the same line with Nazim et al. (2013).

As food products containing 1-25\% fat was defined as low fat, while 25-45\% as medium fat (Codex, 2016). The croissant pastry with spreadable tofu blends could be categorized as medium-fat products.

\section{Water activity:}

Data shown in Table (3) illustrated that water activity of croissant pastry samples at zero time ranged from 0.879 to 0.912 and after storage for 3 days ranged 0.837 to 0.880 . These results are in the same line with those of Linda and Stan (2008) who noted that water activity in yeasted pastries, e.g. Danish, croissant had 0.9 aw. 


\section{Microbiological properties:}

Obtained data in Table (4) showed that neither yeasts \& molds nor bacteria were detected in all the fresh samples at zero time. .However, after 3 days total plate counts of Croissant pastry samples $(\mathrm{Ct}, \mathrm{Ct} 1, \mathrm{Ct} 2, \mathrm{Ct} 3, \mathrm{Ct} 4$, $\mathrm{Ct5}$ and Ct6) were 3.34, 3.32, 3.28, 3.39, 3.1, 3.55and $3.47 \mathrm{log} \mathrm{cfu} / \mathrm{g}$, respectively, and yeasts \& molds reached $2.7,2.34,3.35,3.6,3.65,3.53$ and $3.68 \log \mathrm{cfu} / \mathrm{g}$.

These findings confirmed those of Hozova et al. (2002) who found that the yeast count in croissant is not included in the standard, and maximum limit for the mold count in this type of product is $5 \times 102 / \mathrm{g}$ ).

\section{Sensory evaluation:}

Data in Figures 6 - 13 showed that the sensory test of croissant pastry samples proved the superiority of green olive sample compared to pepper sample. Meanwhile, peach sample showed higher acceptability score than guava, however, Control spreadable tofu was less acceptable than all the other samples. Taste and odor scores of Ct6 demonstrated the highest values compared to other samples. However, for the other sensory attributes; i. e. texture, shape, crust appearance, layer formation and crumb color showed slight differences among the different samples.

These results confirmed the similar trend found by EL-Boraey et al. (2015) who explained that the beany taste and flavor undoubtedly were the principal reasons for the declining of soymilk scores.

As Agrahar, (2014) mentioned that taste and flavor are the two very important constituents to like or dislike a product. The presence of beany flavor and off smell of soy products used to be one of the biggest hindrances in its promotion as a healthy food. Food additives are known to reduce the undesirable flavors such as beany to a minimum and maximize total acceptability for tofu, and good color characteristics was found highly acceptable by panelists.

In this respect, Shalaby and Yasin (2013) pointed out that the bread and other bakery product like croissant have an important role in human nutrition. Therefore, there have been many investigations to enhance the 
nutritive value of these products to produce tasteful croissant-type products filled with various kinds of cream or cheese that are favored especially by children population.

Table (1): Formulation of ingredients in different spreadable tofu blends

\begin{tabular}{|c|c|c|c|c|c|c||}
\hline \multirow{2}{*}{ Ingredients } & \multicolumn{5}{|c|}{ Spreadable tofu blends (g) } \\
\cline { 2 - 7 } & Control & T1 & T2 & T3 & T4 & T5 \\
\hline \hline Soy curd & 454.75 & 404.75 & 427.75 & 434.75 & 395.18 & 447.15 \\
\hline Skim milk powder & 50 & 50 & 50 & 50 & 50 & 50 \\
\hline Whey powder & 30 & 30 & 30 & 30 & 30 & 30 \\
\hline Palm oil & 172.03 & 170 & 176.45 & 174 & 182.13 & 189.33 \\
\hline Q3 & 30 & 35 & 38 & 30 & 40 & 45 \\
\hline Emulsifying salts & 25 & 25 & 25 & 25 & 25 & 25 \\
\hline Chopped green olives & --- & 50 & --- & --- & --- & -- \\
\hline $0.2 \%$ ground black pepper and & --- & --- & 27 & --- & --- & --- \\
$2.5 \%$ chopped green peppers & & & & & & \\
\hline Sugar & --- & --- & -- & 20 & --- & -- \\
\hline Guava pulp & --- & --- & --- & --- & 200 & -- \\
\hline Peach pulp & --- & --- & --- & --- & --- & 150 \\
\hline Water & 238.22 & 235.25 & 225.9 & 236.35 & 77.69 & 63.52 \\
\hline Total & 1000 & 1000 & 1000 & 1000 & 1000 & 1000 \\
\hline
\end{tabular}

C: control spreadable tofu without any flavor, T1:spreadable tofu with Chopped green olives, T2: spreadable tofu with Mix ground black pepper and chopped green peppers, T3: spreadable tofu with sugar; T4: spreadable tofu with guava pulp, T5: spreadable tofu with peach pulp. 
- Using spreadable tofu blends in the preparation of croissants

Table 2. Croissant pastry samples

\begin{tabular}{|c|l||}
\hline Treatments & Croissant pastry Samples \\
\hline \hline $\mathrm{Ct}$ & Control croissant sample \\
\hline $\mathrm{Ct} 1$ & Croissant with spreadable tofu only \\
\hline $\mathrm{Ct} 2$ & Croissant with spreadable tofu and Chopped green olives \\
\hline $\mathrm{Ct} 3$ & $\begin{array}{l}\text { Croissant of spreadable tofu with ground black pepper and } \\
\text { chopped green peppers }\end{array}$ \\
\hline $\mathrm{Ct} 4$ & Croissant with spreadable tofu with sugar \\
\hline $\mathrm{Ct} 5$ & Croissant of spreadable tofu with guava pulp \\
\hline $\mathrm{Ct} 6$ & Croissant of spreadable tofu with peach pulp. \\
\hline
\end{tabular}

Table 3. Water activity of croissant pastry blends

\begin{tabular}{|c||c|c|c||}
\hline \multirow{2}{*}{ Croissant pastry blends } & \multicolumn{3}{|c||}{ Storage period } \\
\cline { 2 - 4 } & Zero time & 1 Day & 3 Day \\
\hline \hline $\mathrm{Ct}$ & 0.879 & 0.873 & 0.859 \\
\hline $\mathrm{Ct} 1$ & 0.907 & 0.883 & 0.837 \\
\hline $\mathrm{Ct} 2$ & 0.910 & 0.880 & 0.849 \\
\hline $\mathrm{Ct} 3$ & 0.905 & 0.877 & 0.845 \\
\hline $\mathrm{Ct} 4$ & 0.888 & 0.883 & 0.880 \\
\hline $\mathrm{Ct} 5$ & 0.910 & 0.879 & 0.871 \\
\hline $\mathrm{Ct} 6$ & 0.912 & 0.885 & 0.867 \\
\hline
\end{tabular}

$\mathrm{Ct}$ : control croissant sample; $\mathrm{Ct} 1$ : croissant with spreadable tofu only; $\mathrm{Ct} 2$ : croissant with spreadable tofu and Chopped green olives, Ct3: croissant of spreadable tofu with ground black pepper and chopped green peppers, $\mathrm{Ct} 4$ : 
croissant with spreadable tofu with sugar; Ct5: croissant of spreadable tofu with guava pulp, Ct6: croissant of spreadable tofu with peach pulp.

Table 4. Microbiological properties of croissant pastry blends (log cfu/g):

\begin{tabular}{|c|c|c|c|c|c|c||}
\hline \multirow{2}{*}{ croissant pastry samples } & \multicolumn{3}{|c|}{ Total plat count } & \multicolumn{3}{c|}{ Yeast and mould } \\
\cline { 2 - 8 } & Fresh & 1 day & 3 day & Fresh & 1 day & 3 day \\
\hline \hline $\mathrm{Ct}$ & 0 & 1.3 & 3.4 & 0 & 1.1 & 2.7 \\
\hline $\mathrm{Ct} 1$ & 0 & 1.5 & 3.32 & 0 & 1.75 & 2.34 \\
\hline $\mathrm{Ct} 2$ & 0 & 1.33 & 3.28 & 0 & 1.8 & 3.35 \\
\hline $\mathrm{Ct} 3$ & 0 & 1.11 & 3.39 & 0 & 1.91 & 3.6 \\
\hline $\mathrm{Ct} 4$ & 0 & 1.24 & 3.1 & 0 & 2.13 & 3.65 \\
\hline $\mathrm{Ct} 5$ & 0 & 1.52 & 3.55 & 0 & 2.1 & 3.53 \\
\hline $\mathrm{Ct} 6$ & 0 & 1.57 & 3.47 & 0 & 2.15 & 3.68 \\
\hline
\end{tabular}

$\mathrm{Ct}$ : control croissant pastry blends without any flavor, $\mathrm{Ct} 1$ : croissant with spreadable tofu only, $\mathrm{Ct} 2$ : croissant of spreadable tofu with Chopped green olives, Ct3: croissant of spreadable tofu with Mix ground black pepper and chopped green peppers, $\mathrm{Ct} 4$ : croissant of spreadable tofu with sugar; $\mathrm{Ct} 5$ : croissant of spreadable tofu with guava pulp, Ct6: croissant of spreadable tofu with peach pulp. 
Figure 1: Moisture contents of croissant samples
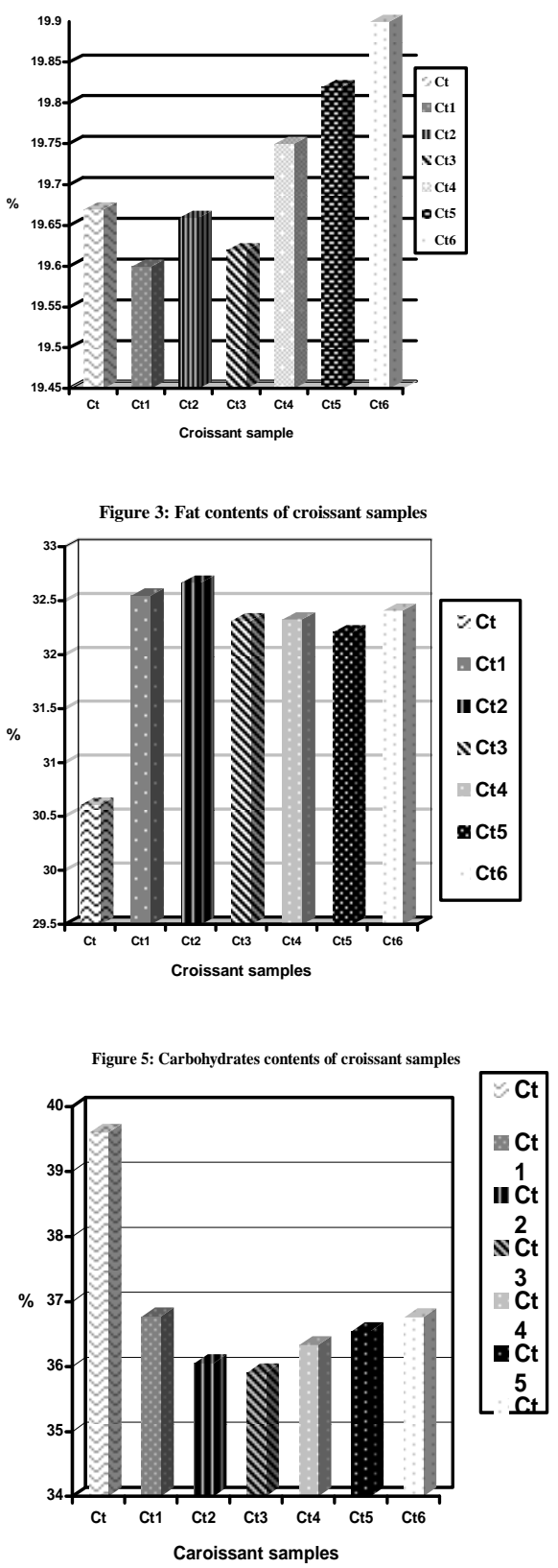

Figure 2: Protein contents of croissant samples

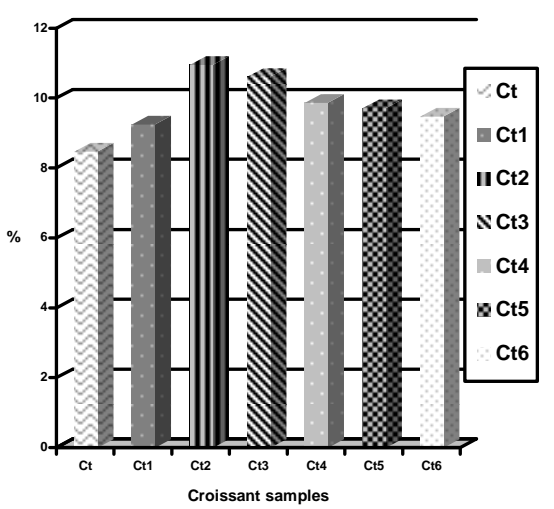

Figure 4: Ash contents of croissant samples

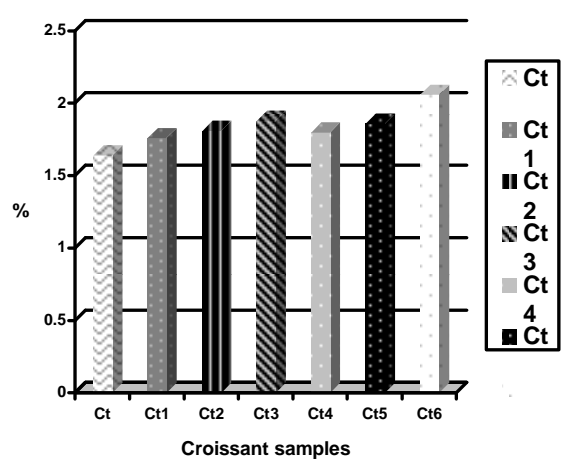

Figure 6: Taste scores of croissant sample

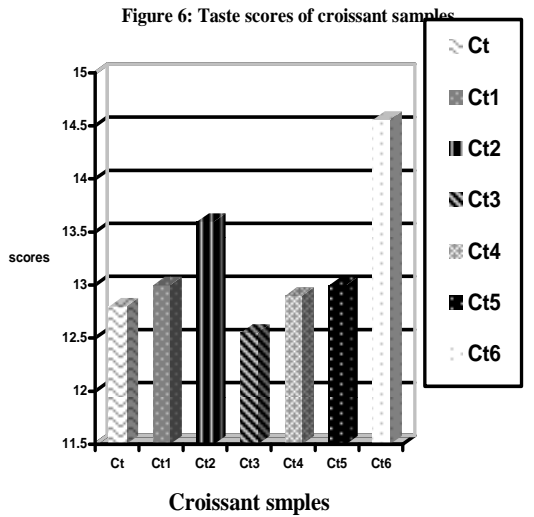




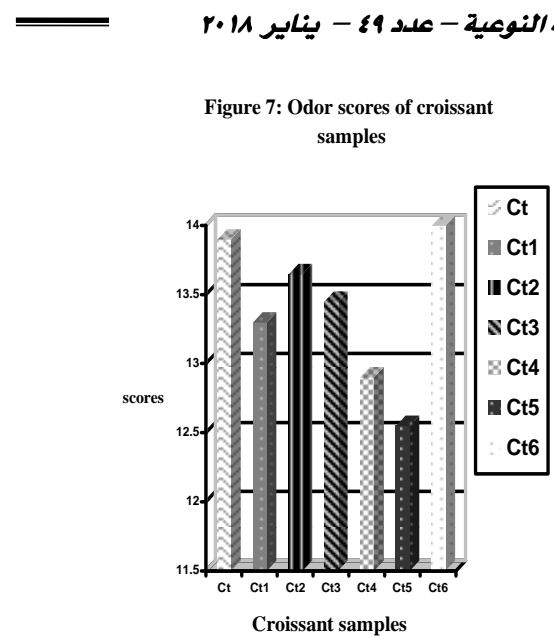

Figure 9: Shape scores of croisant samples
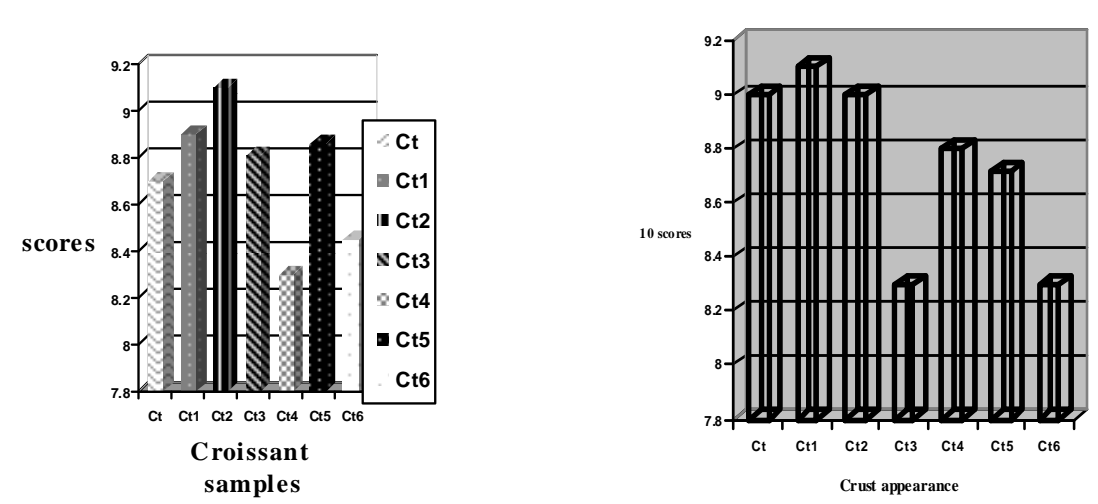

Figure 11: Sensory evaluation of croissant samples

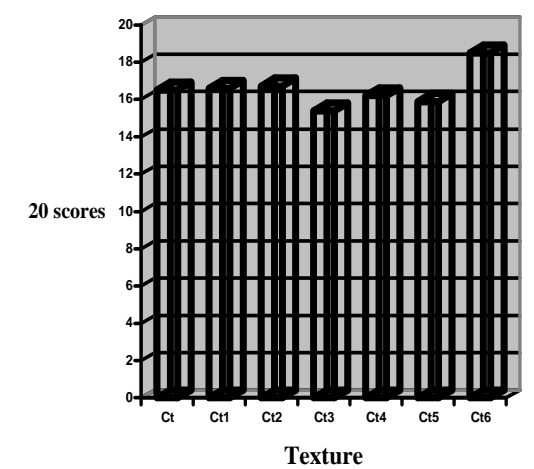

Figure 10: Sensory evaluation of croissant samples

Figure 12: Crumb color of croissant samples
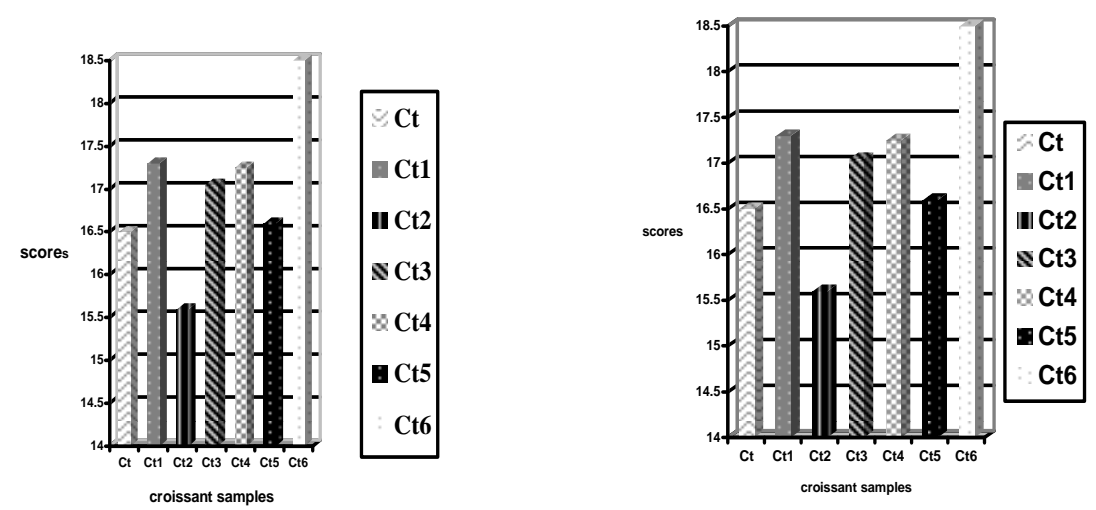


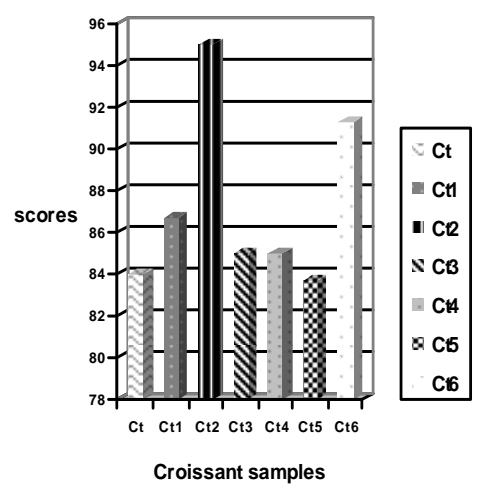

\section{References}

- Abou- Dobara, M. I.; Ismail , M. M. and Refaat, N. M.(2016). Chemical composition, sensory evaluation and starter activity in cow, soy, peanut and rice milk. Journal of Nutritional Health \& Food Engineering, 5(3):1-8.

- Aisbitt B., Caswell, H., and Lunn, J. (2008). Cereals - current and emerging nutritional issues. J Nutr Bullet 33(3):169-185.

- Agrahar, M. (2014). Effect of sprouting of soybean on the chemical composition and quality of soymilk and tofu. J Food Sci Technol. 51(5): 915921.

- A.O.A.C. (2005). Official Methods of analysis of association of official analytical chemists. $19^{\text {th }}$ Ed., The Association of Official Analytical Chemists. Arlington, West Virginia, USA.

- A.O.A.C. (2012). Official Methods of analysis of association of official analytical chemists. $19^{\text {th }}$ Ed., Vol. (2), The Association of Official Analytical Chemists. Arlington, West Virginia, USA.

- Awad, R. A. ; Salama, W. M. and Farahat, A. M. (2014). Effect of lupine as cheese base subtitution on technological and Nutritional properties of processed cheese analogue. Acta Sci. Pol., Technol. Aliment., 13(1): 55-64. 
- Benassi,V. T.; Yamashita, F. ; and Prudencio, S. H. (2011). A statistical approach to define some tofu processing conditions, Ciênc. Tecnol. Aliment., Campinas, 31(4): 897-904.

- Borneo R, and León AE (2012). Whole grain cereals: functional components and health benefits. Food Funct., 3(2):110-119.

- Bennion,E.b. and Bamford,G.S.T.(1983). Thetechnology of cake making. An Intertext Publisher, Leonard Hill Books.

- Chikere, C.B. and Udochukwu, U. (2014). Effect of growth and incubation time on the culturability of soil bacteria. IOSR Journal of Pharmacy and Biological Science, 9(2): 6-9.

- CODEX (2016). Codex Alimenterius (International Food Standards). General Standard for Food Additive. FAO/WHO. CODEX STAN192-1995. (http://www.codexalimentarius.org/standards/en/).

- EL-Boraey NA, Ismail MM, Hoda FA Elashrey (2015). Chemical composition, sensory evaluation, rheological properties and starter activity of admixtures of buffalo's, cow's and soymilk. American J. Food Science and Nutrition Research, 2(4): 119-127.

- Farahmandfar, R. ; Mazaheri T. M.; Razavi, S. M. A. and Habibi N. M. B. (2010). Effect of soy cheese and trisodium citrate on pizza cheese. International Journal of Food Engineering ,6(5): 1-9.

- Hozova, B.; Kukurova, I.; Turicova, R.; and Dodok, L. (2002): Sensory quality of stored croissant-type bakery products. Czech J. Food Sci., 20: 105112.

- Katase, M and Tsumura, K. (2011). Original Article: Enumeration of microorganisms in processed soy products with an automated most probable number method compared with standard plate method. Letters in Applied Microbiology, Analytical Center for Food Safety, Quality Assurance Department, Fuji Oil Co., Ltd, 1 Sumiyoshi-Cho, Izumisano, Osaka, Japan .

katase.mitsuru@so.fujioil.co.jp.

- Linda, Y. and Stan, C. (2008). Water - a special ingredient in baking. ABF Ingredients, 05: 42-46. 
- Massoud, R.; KhosRAvi-DARAni, K.; NAKhsAz, F. and VARgA4, L. (2016). Evaluation of physicochemical, microbiological and sensory properties of croissants fortified with Arthrospira platensis (Spirulina). Czech J. Food Sci., 34: 350-355.

- Nazim, M. U., *Mitra, K., Rahman, M. M., Abdullah, A. T. M. and Parveen, S. (2013). Evaluation of the nutritional quality and microbiological analysis of newly developed soya cheese. International Food Research Journal, 20(6): 3373-3380.

- Petrak L. (2008.) Ingredients technology: Bean counters perceived health benefits and cost advantages sper new ingredient technologies and a range of soy products. Snack Food and Wholesale Bakery, 30: 33-37.

- Rosell, C.M. and Garzon, R. (2015). Chemical composition of bakery products. Handbook of Food Chemistry, Springer-Verlag Berlin Heidelberg, p. 28 .

- Shalaby, S. M. and Yasin, N. M. N. (2013). Quality characteristics of croissant stuffed with imitation processed cheese containing microalgae chlorella vulgaris biomass. World Journal of Dairy \& Food Sciences, 8(1): 58-66.

- Smith, C.E., and Tucker K.L. (2011). Health benefits of cereal fiber: a review of clinical trials. Nutr. Res. Rev., 24(1):118-131.

- Sternhagen L.G. and Hoseney, R.C. (1994). Firming effects in danish pastry. Cereal Chem. 71(6):560-563.

- Yu, L.L., Tsao, R., and Shahidi, F. (2012). Cereals and pulses: nutraceutical properties and health benefits. Wiley-Blackwell, Ames.

- Zeiny, A. R. ; A. O. Shalaby ; Fatima M. Zemzemi and Omnia A. Awad (2015). Effect of croissant supplemented with honey and propolis on aspirininduced stomach ulceration in rats. J. Food and Dairy Sci., 6 (3): 177 - 191. 


\section{استخدام خلطات التوفو القابلة للفرد في تخضير الكرواسان}

$$
\text { الملخص الصربي }
$$

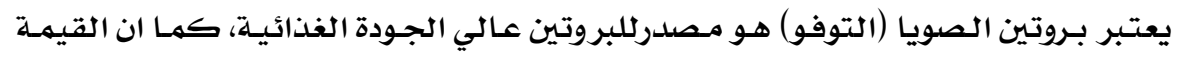

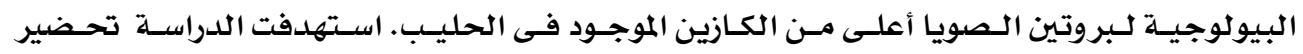

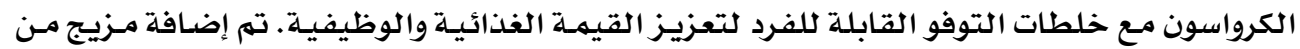

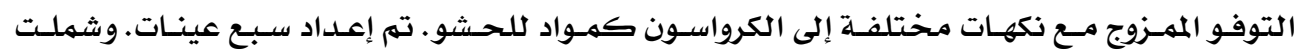

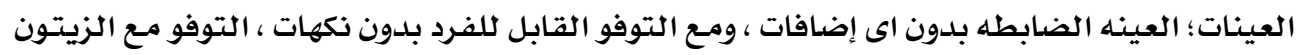

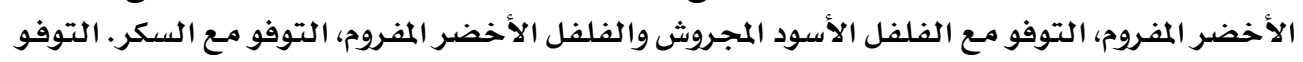

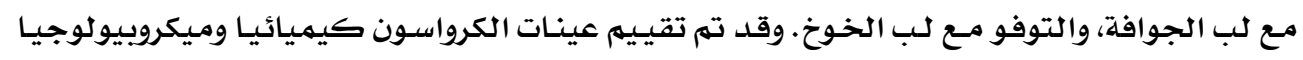

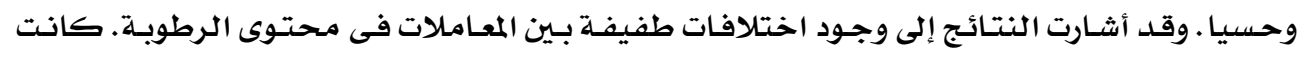

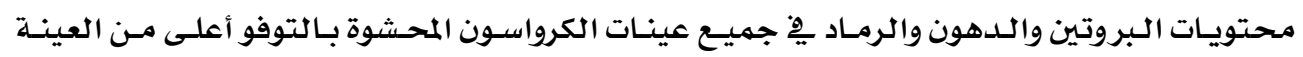

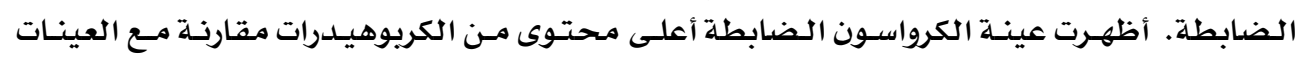

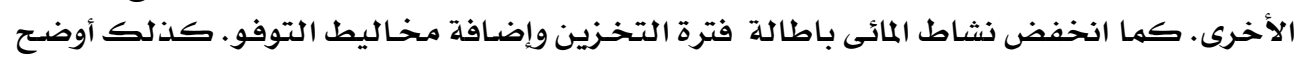

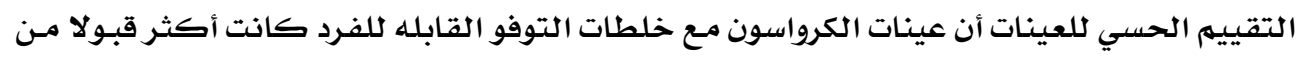

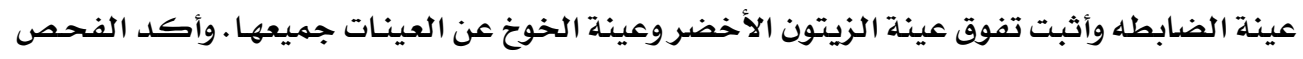

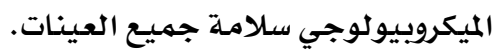

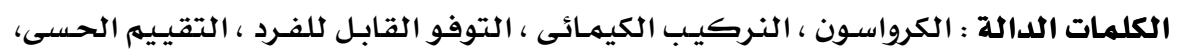
الفحص الميكروبيولوجى ، النشاط المائي. 